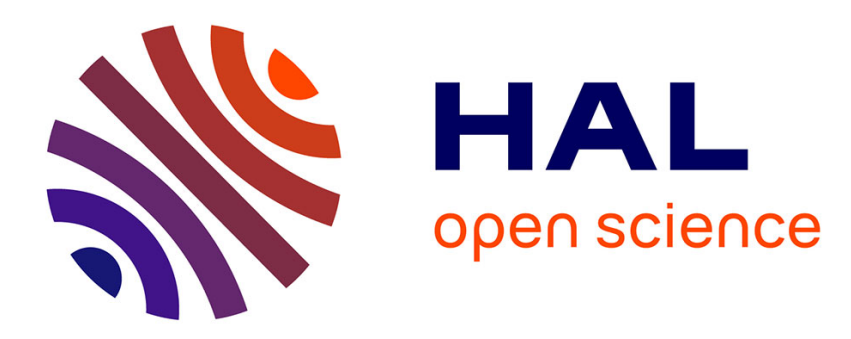

\title{
Corporate governance and profit manipulation: a French field study
}

Caroline Lambert, Samuel Sponem

\section{To cite this version:}

Caroline Lambert, Samuel Sponem. Corporate governance and profit manipulation: a French field study. Critical Perspectives On Accounting, 2005, 16 (6), pp.717-748. 10.1016/j.cpa.2003.08.008 . halshs-00170340

\section{HAL Id: halshs-00170340 \\ https://shs.hal.science/halshs-00170340}

Submitted on 22 Mar 2010

HAL is a multi-disciplinary open access archive for the deposit and dissemination of scientific research documents, whether they are published or not. The documents may come from teaching and research institutions in France or abroad, or from public or private research centers.
L'archive ouverte pluridisciplinaire HAL, est destinée au dépôt et à la diffusion de documents scientifiques de niveau recherche, publiés ou non, émanant des établissements d'enseignement et de recherche français ou étrangers, des laboratoires publics ou privés. 


\title{
CORPORATE GOVERNANCE AND PROFIT MANIPULATION: A FRENCH FIELD STUDY
}

\author{
CAROLINE LAMBERT \\ SAMUEL SPONEM* \\ CREFIGE, Université Paris-IX Dauphine, Pl. du Maréchal de Lattre de Tassigny, \\ 75775 Paris Cedex 16, France
}

\begin{abstract}
Profit manipulation has been largely studied through Positive Accounting Theory (PAT). However, the weakness of the results obtained would suggest using different theoretical and methodological approaches to examine this subject. In France, management controllers play a central role in profit manipulation. This paper offers a comprehensive analysis of their profit manipulation practices. Using results from 32 interviews in 13 companies, we argue that the spread of Anglo-Saxon corporate governance model has fostered such behaviour. Far from the opportunism hypothesis supported by positive accounting theory, profit manipulation is used as a tool by management controllers to gain broader legitimacy within organizations and/or to adopt what they claim to be ethical behaviour.
\end{abstract}

Key words: profit manipulation, management controllers, corporate governance, field study

\footnotetext{
* Address for correspondence: Samuel Sponem, CREFIGE, Université Paris-IX Dauphine, Place du Maréchal de Lattre de Tassigny, 75775 Paris Cedex 16, France. E-mail: sponem@crefige.dauphine.fr
} 


\section{Introduction}

In the light of recent corporate scandals, accounting today as an objective way of presenting economic reality is suffering from a real crisis of confidence. Central to the Anglo-Saxon system of corporate governance, it has been pushed into the public spotlight, where its impartiality and objectivity is being questioned.

Even though most of the scandals have taken place in the United States, the crisis of confidence has had an impact far beyond US borders, as the Anglo-Saxon system of governance is spreading throughout continental Europe and particularly in France (Pesqueux, 2000).

In order to contain the crisis, the United States and France are committed to institutional and legal reform. Moreover, those identified as having perpetrated such manipulation, essentially auditors and financial directors, have been legally sanctioned. We should nonetheless question whether these legal and legislative measures will be sufficient to restore long-term confidence in the system. Shouldn't the social dimension of the issue be taken into account (Colasse, 2003)? Isn't it necessary first to understand the reasons behind profit manipulation and how it functions before changing legislation?

Tenants of Positive Accounting Theory (PAT) have represented the mainstream of accounting research since the early 80s. They see profit manipulation, which they euphemistically call "earnings management", from an exclusively economic standpoint. Due to poor empirical results, this program of research has led to a crisis in accountancy research today (Reiter, 1998) and teaches us little about the behaviour of the actors in this field. Indeed, Macintosh (1995, p.296) emphasises the "need to know a lot more about the profit manipulation behaviour of managers in organizations".

In this article, we have opted for a comprehensive and sociological perspective in exploring the reasons behind the increased adoption of profit manipulation. Such manipulations affect both internal and external reporting (Macintosh, 1995). We will focus on manipulation of internal reporting, which is now closely related to external reporting (Macintosh, 1995). Since the guardians of internal information reliability in France are, to a large extent, management controllers, we have gathered data from this group of people.

The purpose of this article is to bring together several components in order to construct a answer to the following question: How and why do management controllers take part in profit manipulation? Using theoretical and practical investigation, this study aims to understand the influence that corporate governance may exert on profit manipulation in major organisations.

Analysing interview data from thirteen companies in France has persuaded us that shareholder pressure leads management controllers to manipulate their firm's profits. Going

\footnotetext{
${ }^{1}$ The choice of terms is not a benign one. This expression hides the fact that earnings are the part that goes to capitalists after fighting with the other parties involved. It gives the impression that it is simply a measure of economic efficiency (Tinker, 1980).
} 
beyond individual responsibility, our research shows that the organisation imposed on a company by its shareholders with the aim of respecting criteria of Anglo-Saxon corporate governance is itself the cause of accounting manipulation at all levels.

First, we will define the notion of "earnings management", present a range of practices, and assess the role of management controllers in this phenomenon. We will then present our analysis of the empirical data. We will observe that management controllers implement different methods for manipulating profit. Then, we will propose a model to explain the behaviour of management controllers in companies in France, highlighting the influence of corporate governance and shareholder pressure. Skill in profit manipulation enables management controllers to gain legitimacy in the eyes of managers working in a cultural context that is traditionally difficult for them. They soon become indispensable strategic allies playing the role of arbiter between the markets' short-sightedness and the imperatives of operational management. The results presented will enable us to analyse the relevance of an Anglo-Saxon model of governance to a French cultural context and the inherent contradictions of its theoretical foundation: agency theory.

\section{Profit Manipulation: an Overview}

\section{Definition and Incentives}

Schipper (1989, p.92) proposes a representative academic definition of profit manipulation that she refers to as "earnings management", similarly to the vast majority of literature on this subject. She defines profit manipulation as: "a purposeful intervention in the external financial reporting process, with the intent of obtaining some private gain”.

Healy and Walhen (1999, p.370) identify two main incentives for profit manipulation: contracts written in terms of accounting numbers; and capital market expectations and valuation.

The first perspective is supported by the tenants of positive accounting theory (Watts \& Zimmerman, 1990). They suggest that contracts between the firm and its stakeholders create incentives for earnings management. Precisely, they propose three hypotheses (Watts \& Zimmerman, 1990, p.138): the bonus plan hypothesis (directors who benefit from bonuses tied to profits are more prone to using accounting techniques that transfer future profits into the present); the debt/equity hypothesis (the more a company is in debt, the more it is in its interest to focus on present earnings because debt covenants, common in the United States, require certain levels of profitability); and the political cost hypothesis (the larger a company, the more it is in its interest to postpone its profits until a future accounting period to face any risk of burdensome legislation being implemented).

The second perspective suggests that the goal of earnings manipulation is to be in line with the expectations of the financial markets. Dechow and Skinner (2000, p.247) underline that academics have mainly focused on contractual incentives, much more than on the influence of 
capital markets on earnings management and that "this focus has been sustained by the assumption that markets are efficient".

\section{Profit Manipulation: a Range of Practices}

Profit manipulation can take two forms: earnings management and falsification (Merchant, 1990, p.300). Earnings management involves postponing the period affected by an operation by changing the measurement methods ${ }^{2}$, speeding up a sale or delaying a purchase. Here, we can make out in the background earnings management as limited to manipulating accounting figures, rather than to profit manipulation that involves acting on real business situations. Falsification involves disclosing wrongful data. In this case, such actions may be considered criminal. However, the fine line between these two types of manipulation remains blurred.

Several profit manipulation strategies can be applied: smoothing reduces the variance of earnings and therefore to reduce perceived risk; big bath accounting wipes the slate clean for a new appointed director; or quite simply opportunistic management, the phenomenon supported by tenants of positive accounting theory. Long before the Enron and Worldcom scandals, SEC chairman Arthur Levitt (1998) condemned the "game of nods and winks" during a speech at New York University, and portrayed "the game that runs counter to the very principles behind the market's strength and success". He identified some of the most popular practices of earnings management: "big bath" restructuring charges, creative acquisition accounting, "cookie jar reserves", "immaterial" misapplications of accounting principles, and the premature recognition of revenue. Crossing these practices with the typology proposed by Dechow \& Skinner (2000) provides a comprehensive presentation of the practices most observed currently, whether or not they violate GAAP (see Table 1).

These examples highlight common U.S. and French practices of earnings management. We observe that practices do not fundamentally differ, but are adapted to local accounting rules. Some of these techniques are the privilege of "headquarters" level, i.e. boardrooms deciding to manipulate corporate results so that consolidated accounts provide the "expected" figures. Other practices presented below are also used at other levels in the organisations.

Regarding the scarcity of French examples, the inefficiency of the COB (Commission des Opérations de Bourse), the French equivalent to SEC, is frequently underlined. For instance, in the Vivendi Universal case, " the COB, which have begun an inquiry fifteen days after the fall down of J.M. Messier, and which should have rapidly written a report, still have not disclosed anything. Two full-time reviewers alone are dedicated to this layer, for examining the seized materials, enclosed the 80 tons sent by the SEC last February. We can observe the same discretion from the financial squad. Following a spectacular search in December 2002, at Vivendi headquarters and at the major protagonists' offices, and then discrete inquiries at Goldman Sachs, in April, everything came down to silence. Even the political and the business circles proved a lack of concern." (Orange, 2003)

\section{< Insert Table 1 Here >}

\footnotetext{
${ }^{2}$ For example, by choosing what events are taken into account in a given period, the number of periods affected by an event and the impact on each period, and the way of classifying events in the profit \& loss account (Stolowy \& Breton, 2000, p.31)
} 


\section{< Insert Table 1 (continued-1) Here >}

\section{< Insert Table 1 (continued-2) Here >}

\section{Choosing a Different Level of Analysis to Study Profit Manipulation?}

PAT researchers almost exclusively focus on top-management level profit manipulation. We deny the hypothesis according to which the director is alone in making accounting decisions. The fact that accounting documents of large are the aggregation of accounting documents drawn up by managers with their own incentives and priorities may explain the divergences that appear in the empirical results of various studies conducted into earnings management. Internal contracting, most often covered in PAT, deals with the compensation hypothesis. In this area, results from different studies are contradictory (Guidry et al., 1999, p.114). Few studies in the context of PAT look at internal earnings management. Using data gathered from more than one hundred business units of one firm, Guidry et al. (1999, p. 114) show that business-unit managers manage earnings to obtain their bonuses. Ronen, Sadan and Snow (1977, p.12-13) assert that: "smoothing could be destined to (1) external users of financial statements, such as investors and creditors, and (2) management itself. More specifically, as far as management is concerned, it should be noted that the motivation to smooth income is not confined to top management. Lower management may attempt to smooth to look good to the top management. They may try to meet predetermined budgets, which in addition to serving as forecasts, also act as performance yardsticks" (quoted by Stolowy \& Breton, 2000, p.35). Similarly, Merchant (1990, p.297) states how data collected on profit manipulation at the highest levels of an organisation with a view to understanding profit manipulation is of little relevance. Using interview data, Merchant (1990) also points out that most business unit managers manipulate the performance of their units.

There are few empirical studies on internal profit manipulation outside the scope of PAT. However, studies by Merchant (1990) and Berry and Otley (1975) are noteworthy. Using interviews complemented by questionnaires, Merchant states, "pressure to reach net earnings or budgeted expenses encourages managers to move earnings from year to year by manipulating the accounts" (Merchant, 1990, p.305). Using case studies, Berry and Otley (1975) show that profit manipulation depends in large part on the forecasting process. In fact, "at each level in the organization expectations may be established in one of three ways. Firstly, an independent estimate can be reached independently from any other in the organization. Secondly, an estimate can be reached by aggregating estimates made by lower levels in the organization [...]. Thirdly, an estimate can be reached by disaggregating a higher level estimate" (Berry and Otley, 1975, p.176-177). Berry and Otley (1975, p.188-189) assert that one response to failure in reaching forecasts is "creative book-keeping [...] there was evidence of a cross allocation of costs in order to protect units from external criticism and to protect reputation. The organization of such protection was an imaginative task for the accounting staff." Lastly, they highlight another factor which explains profit manipulation: "The result of these case studies indicates that the interdependence of forecasts at different levels when forecasts have been made by disaggregating [...] may encourage managers to take a series of defensive positions and make the information and reporting systems opaque" (Berry and Otley, 1975, p.190). This study suggests that how much profit manipulation takes 
place does not only depend on how accounting is used to evaluate the performance of managers and their pay but also how forecasts are made that will be used as a baseline for such performance appraisal. Thus, the remuneration hypothesis put forward in the PAT does not suffice to explain internal profit manipulation.

\section{The Management Controller's Role}

Discussing an article by Nelson et al. (2002) entitled "Evidence from Auditors about Managers' and Auditors' Earnings Management Decisions", Gibbins (2002, p.205) asks to see "the auditor's role more fully developed and more distinguished from management's intents". Richard and Reix (2002) propose a rich analysis of the relationship between the finance director and the auditor in the audit process and its effects on the audit quality. Adopting a similar thought process, we have decided to focus on the management controller's role and relationships with managers in the profit manipulation mechanism.

The person who manages forecasting and consolidation of accounts in France is the management controller. If profit manipulation takes place, it is crucial to understand how and why the management controller would be driven to take part in it, when this role is the contrary to what the literature would lead us to believe.

The central problem of management control is the convergence of the organisation's goals with those of its members (Anthony \& Govindarajan, 2001, 1965). In other words, management control must be envisaged as understanding implicit decision-making processes, taking into account the reciprocal impact on the decision-making process of networks and identities inside, as well as outside, the organisation (Mintzberg, 1983). The management controller's primary mission is to promote this convergence of goals whilst taking into account the reciprocal influence of networks and identities.

With this in mind, information plays a crucial role (Simon et al., 1955). In theory, the management controller's responsibility towards information should be similar to that of a telecommunications company which guarantees that messages circulate throughout the system in a clear, precise and rapid manner, without being responsible for their content or for acting upon the information they contain (Anthony, 1988). The central problem here derives from the ambiguity relating to the hierarchical and functional attachments of the controller who is in charge of this mission (Bouquin, 2001). The controller delivers information to managers but must also gather it from them in order to provide the board with "the right signals", and to manage the risks taken by operational managers effectively. If he wishes to remain guardian of information reliability, he must display unwavering loyalty towards head office. But, in that case, how can he avoid being perceived as Big Brother's lapdog by operational managers? Moreover, he is running the additional risk in this situation of being sidelined from the truly relevant information, that which lies at the heart of the decisionmaking process. 


\section{Sample and Method}

How can we collect data on a subject as sensitive as manipulating profits? Indeed, "despite the popular wisdom that earnings management exists, it has been remarkably difficult for researchers to convincingly document it" (Healy and Wahlen, 1999, p.370).

Using one of Copeland's typologies (1968, p.105), Stolowy and Breton (2000) identify three types of empirical tests for earnings manipulation: (1) directly ascertaining from management by interview, questionnaire, or observation; (2) asking other parties such as CPA's; or (3) examining financial statements and/or reports to governmental agencies to verify, ex post, if smoothing has occurred.

Therefore, earnings management can be studied in two different ways. A so-called "objective way" is using accounting documents. Another method of collecting data is to use the statements made by managers, accountants and auditors. PAT's answer is to use objective measures extrapolated from financial statements. For our study, we are looking to understand how profit manipulation is developed within organisations and therefore we need to adopt a more "comprehensive" standpoint.

In this case, data gathering was conducted using semi-directive interviews. Thirty-two management controllers belonging to thirteen different companies were interviewed on the relatively general theme of their daily activity. During the interview, either in response to a question that arose naturally or spontaneously, they mentioned taking part in profit manipulation. This method's main advantage is offering access to a set of explanations provided by the controller himself. We have therefore focused our analysis on this explanatory material, particularly rich in lessons for understanding behaviour relating to earnings management. The primary limitation is the conscious desire not to put the interviewee on the defensive. As such, some questions remained unanswered by some of the controllers. We are interested in management controllers at varying staff levels because an individual's views and participation in profit manipulation may vary according to rank.

\section{<Insert Table 2 Here >}

\section{Management Controllers and Profit Manipulation}

Management controllers actively participate in profit manipulation. Several of them we were able to get close to described the kind of operations they'd performed in detail. Due to the very sensitive nature of the question, other controllers mentioned the importance of their accountancy skills or their experiences as auditors in their daily routine.

The work that management controllers perform varies from simple "beautifying"presentation know-how, increasingly highlighted as a quality essential to being a good management controller - to considerably more significant actions which resemble "cosmetic surgery under general anaesthetic". 


\section{From Simple Work on Presentation...}

There is much work on presentation, and communication is also important. We are here to say what is going on, but also to spotlight what is working well. Even if this is just to prepare the content of a financial statement later on.

(Oil and Gas Industry, Zone Management Controller $\mathrm{N}^{\circ} 1$ ).

When you address members of the Board of Directors, you spend enormous amounts of time writing notes and doing presentations. [...] Between two people, the one who will stand out is the one who gives the better presentation. That's what we are appreciated for, it's just the tip of the iceberg... (Beverages, Zone Management Controller $\mathrm{N}^{\circ} 1$ )

The importance of this work on presentation appears to be growing. It seems to be an absolutely essential skill for advancing in the profession.

Towards the end of the period, you spend a day or two crunching numbers to produce something that holds water. Then, another important point in the controller's routine, once he's done his number crunching, is spending three days doing a presentation for the Board of Directors. [...]

That means, when someone asks a question, you are able to answer immediately either: 1/ I know where to find the information; 2/ I think I know how to shed a different light on it; 3/ I know how to integrate it into a table; 4/ I know how to present it in fine. That's what I call the ability to model.

(Beverages, Zone Management Controller $\mathrm{N}^{\circ} 2$ )

We are far from an objective and impartial accounting presentation that is rationally used in the decision-making process as assumed by PAT and agency theory (Baiman, 1990). It largely becomes a construct whose form matters as much as it's content.

\section{...to Profit Manipulation}

Earnings management by companies is seen by a large number of controllers as a given. And controller participation in this process is widely recognised.

All of the big groups pilot their results. They do what they want.

(Media and Entertainment 2, Operational Management Controller)

Without giving details of the techniques used, some controllers emphasise their accounting skills. A second branch management controller from the Oil and Gas Industry confided that he spent the largest part of his time answering questions on accounting from operational managers looking to optimise management of their accounts:

At my level, you are asked lots of questions like: "How do we deal with this, how do we deal with that?" This is also due to my previous experience in a subsidiary in charge of the group's consolidation for four years. I have an accounting background [...] so I'm asked a lot of questions about accounting and how to optimise things. Looking into these questions takes up the greatest portion of my time. It's all about talking to people, answering questions, and then looking at the final reports that we prepare for validation.

(Oil and Gas Industry, Branch Management Controller)

The site financial controller for an Automobile and Parts 1 industry emphasised his past experience as auditor. He points out that this sometimes helps in getting around certain questions.

You always have one eye on the accounts, since most of us have experience as auditors, and have an acute awareness of internal control, even if we're not star pupils when it comes to accounting standards. 
The opportunities and choices operated in terms of manipulation at business-unit level seem to depend on the sector of activity. Highly capital-intensive industries, which generate large sums of money for amortisation, have powerful levers at their disposal. In Table 3 below, we present three clear examples of profit manipulation reflexes.

\section{<Insert table 3 Here >}

We are far from what Anthony (1988) presents as the main role of the management controller, the "telecommunications company which guarantees that messages circulate throughout the system in a clear, precise and rapid manner, without being responsible for their content or for acting upon the information they contain." In fact, as underlined by Moriceau and Villette (2001, p.100), the management controllers "wield the magic wand of figures, that magic which enables us to change reality into fact and fact into reality with a single click of the mouse".

\section{Shareholder Pressure and Profit Manipulation}

Management controllers often mention the rise in shareholder pressure as one of the most important change factors in their profession in recent years. The rise in shareholder influence alters the very nature of their task by increasingly focusing on reporting and budgetary control. Shareholder pressure also modifies the relations that controllers maintain with operational managers and what the latter see as the controller's mission. What management controllers say leads us to investigate the link between growing shareholder pressure and significant profit manipulation. Analysing interview content has shown us that the greater the shareholder pressure, the more management controllers tend to take part in profit manipulation.

\section{The Rise in Shareholder Pressure}

Management controllers see the rise in shareholder pressure as being one of the most noticeable changes in their profession over the last ten years.

I was head of finance in a subsidiary, so I had a budgetary function. We looked at earnings from a more accounting angle and we didn't have the same routine and we didn't have the same pressure of results either, that's for sure.

It's like that because, having prioritised things around earnings and reporting, we create earnings expectations. [...] The other important factor is financial communication. Before, we were in a system of half-yearly consolidated results, where things were fairly relaxed. Basically, because earnings for the month of June came out sometime in September, there were relatively few expectations from the financial markets. There were also delays in publication, figures were bigger and consolidation was a lot more difficult. Whereas, today, we publish our earnings on a quarterly basis, within much shorter time periods. The financial markets have expectations, especially when we see what our American competitors are doing... So yes, there is certainly expectations from the financial markets to know rapidly what's happening, where we are...

(Oil and Gas Industry, Zone Management Controller). 
It's starting to change, because, like many other firms, $\mathbf{X}$ is looking towards creating shareholder value and, as a result, is developing this financial culture. That means that whilst one of our priorities is to develop markets and sell more, it is also to generate more profitability for shareholders.

(Food producers and processors, Operational Management Controller)

There are other groups in the Pharmaceuticals and Biotechnology sector, for example Servier, a French group not quoted on the stock market, which does not have this problem at all, because they have no accounts to disclose. They have the profitability of a pharmaceutical group, they are in good financial health, but they do not have performance targets. That means they do more science. They will be more focused on developing their drugs and on bringing them to market, because that is the heart of the matter: you have to produce products and sell them.

(Pharmaceuticals and Biotechnology, Business Unit Controller)

In the Food producers and processors sector as in the Pharmaceuticals and Biotechnology sector, creating shareholder value seems to be an additional and even rival goal, in addition to what they consider to be the company's "true" mission (developing markets, selling more or developing drugs for the Pharmaceuticals and Biotechnology industry). It is interesting to see that management controllers do not consider creating shareholder value as a legitimate goal in absolute terms. In fact, they seem worried that creating shareholder value may damage the company's long-term development.

Transparency becomes a major goal. The branch management controllers in the Oil and Gas industry underline this idea of transparency achieved using accounting documents. These have a two-fold mission: providing internal steering information and communicating to the financial markets.

There is a real need for everyone to increase awareness, because as we disclose results during the first two months, as soon as we have an idea of the result for the quarter, financial communication starts to think about what its message will be. "Are we in line with what we promised or not?" For the guys in foraging and production, their problem is knowing how much they are producing. We have made a promise-we said we were going to increase production of crude. If we don't keep it, we know that our share price will drop.

(Oil and Gas industry, Branch Management Controller $\mathrm{N}^{\circ}$ 2).

The rise in frequency of disclosure, the predominant talk of creating value and transparency, and the diffusion of performance-based remuneration indicate the spread of the Anglo-Saxon model of governance in France.

Corporate governance is characterised by "the whole set of legal, cultural, and institutional arrangements that determine what publicly traded corporations can do, who controls them, how that control is exercised, and how the risks and returns from the activities they undertake are allocated [...] corporate governance can be seen as the institutional matrix that links market signals to the decisions of corporate managers" (Davis \& Useem, 2002, p.235-236). The system of governance in Anglo-Saxon countries is of a "shareholder" type (as opposed to the "stakeholder" model of the countries in continental Europe) (Plihon et al., 2002). Monitoring is performed a posteriori through repurchasing, by financial analysts and shareholder activism (Shleifer \& Vichny, 1997; Davis \& Useem, 2002). In this context, transparency, which stems from reliable accounting information, is one of the criteria of good governance (Jeffers \& Magnier, 2002; Bucham, 2001) and accounting becomes the main 
priority for the directors and all the managers of a company". Accounting "helps the bestperforming firms in the economy to distinguish themselves from poor performers and facilitates efficient resource allocation and stewardship decisions by stakeholders" (Healy and Wahlen, 1999, p.367).

This means that "the representativeness of accounting information has to be guaranteed" and "this can only be achieved with regard to the reliability of internal control procedures in place in the company" (Pesqueux, 2000, p.30). Understanding the mindset that drives the numbercrunching professions, especially management controllers, therefore becomes crucial.

Corporate governance in large French companies is today tending to align itself with the Anglo-Saxon system (Thiery-Dubuisson, 2002) and seems to be manifesting itself in the form of greater shareholder pressure ${ }^{4}$. This pressure has repercussions on the management controller's daily tasks, and on the relations they maintain with operational staff.

\section{Shareholder Pressure and the Management Controller's Activities}

In terms of the tasks themselves, we observe the growing importance of reporting and budgetary control activities, as underlined by a business unit management controller in the Pharmaceuticals and Biotechnology sector:

Because we are part of an American company, we systematically look at the budgetary aspects. I have a friend who works at Servier and it's amusing to note that, even though we have more or less the same position, we don't do the same things at all. He goes to seminars and meetings where they discuss projects between controllers such as setting up ABC... It's a lot more theoretical than what I am doing: I stick to the shop floor. We try to develop maximum collaboration with operational staff on a daily basis, and provide support for a financial approach to projects, for budgetary reallocations, and in the context of an American firm, for budgetary revisions that are close to daily realities, because we have quarterly goals that require very reactive steering.

(Pharmaceuticals and Biotechnology sector, Business Unit Controller)

Our [Management controller's] position is becoming increasingly important, because shareholders are increasingly central to the running of companies. Today, shareholders are less often the man in the street, and increasingly financial groups, such as pension funds. It's increasingly true that the shareholder decides, so if your shareholder is a financier, the company must increasingly think like a financier. So, the financial function is not going to get less important over the coming years, in fact rather the contrary.

(Food producers and processors, Director of Subsidiary Management Control).

\footnotetext{
${ }^{3}$ Fligstein (1990) shows that it has not always been this way. It was in the course of the 20th century that American companies increasingly used accounting documents as a means of control (enabling the control of diversified activities and fulfilling a requirement for raising capital on the financial markets). He notes that in the French model, where the economic sector was controlled to a large extent by the State, control was operated implicitly through the socialisation of civil servants who graduate from the same Grandes Ecoles (Fligstein, 1998). In this environment, accounting is not a major problem. Pesqueux (1999, p.66) adds that, under this model of government, the company is seen "as a technical process which must be governed according to technical specifications" and that public administration management methods are predominant.

${ }^{4}$ Finding factors that explain the growth in corporate governance in companies in France is an issue that stretches far beyond the scope of this article. Nonetheless, we should mention world financial deregulation, the growth of investment funds (Jeffers \& Plihon, 2002) and the floating of major companies on American markets (Davis \& Useem, 2002).
} 
The rise in shareholder pressure seems to have significantly modified the rhythm and the type of work executed by management controllers. They must "think financial communication" in the way they present their results or goals internally, even those in smaller entities. Our interviews confirm the tendency of "integrating the roles of accountant and management controller or making management controllers increasingly obey financial imperatives" (Pesqueux, 2000, p.37).

\section{The Impact of Shareholder Pressure}

Management controllers purposefully cite shareholder pressure as a reason for performing accounting manipulations.

Firstly, it seems that the board's commitment vis-à-vis financial markets drives controllers to manipulate profit in order to cope with the "real life" situations.

What the CEO says when he discloses the results is binding for us. We have to respect our commitments to the financial markets. We have to sweeten the pill in terms of communication. To give an example, we have communicated on our core business, which will result in our selling equipment that is not on tap... But this proves more difficult than expected so we have to move the goal posts for what contracts count as part of our core business.

(Utilities, Headquarters Zone Management Controller)

Since we have large margins in the Pharmaceuticals and Biotechnology sector-there's no secret about that-any slump in sales has a major impact on the bottom line. This loss of earnings has to be compensated for, because the stock market is expecting the results announced. So, we try to compensate for it.

(Pharmaceuticals and Biotechnology sector, Business Unit Controller)

You find yourself hearing things from the financial director like: "What are these figures that keep changing all the time?" You see, they have figures on their minds and, for them, these figures are references. It's true that, give or take a few thousand euros, it doesn't change the world, so that's what they prefer. This is because you have communicated on certain figures that become baseline references. Once they have shown the figures, I can no longer say anything, even if I've made a mistake. So, you play around with things until you get it just right.

(Media and Entertainment 2, Operational Management Controller)

Once, after closure, I had to do the budget again! But this time, I had excellent results. What happened was the CEO was shown a figure, closure took place in December, and things were a complete mess. My budget was way out. So, I asked the units to readjust their budgets for 2003, and they asked me to send the updated budget, post-closure, so as to keep the same overall result as the one shown to the CEO... By putting extra expenses_- "unforeseen costs/revenues" as we call them—in another column, the operational figure was modified, but this didn't change the bottom line. But it could come back to haunt us this year.

(Media and Entertainment 2, Operational Management Controller)

Secondly, the increased frequency of financial communication complicates the task facing management controllers and forces them to recalculate their estimates constantly, making the disclosure of reliable figures difficult.

We are just beginning quarterly consolidation, until now we've been on a more or less half-yearly rhythm. The rule of thumb here is to be as precise and as close as possible to what is going to happen. The management controller has a role of co-steering accounting in a certain number of cases, including the question of smoothing a number of expenses and forecasts. The management controller is drawn to any information which is of a financial nature, such as forecasts, risks, options that we are going to take on such and such a risk... 
Lastly, the pressure of earnings expectations pushes everyone to cover their backs a priori or to manage earnings a posteriori.

Earnings management does take place. When I was working with the director of management control, I accounted for certain figures as unforeseen expenses, as we called them. The branches didn't know about these, and we never knew (and this still remains a mystery) if the CEO could read the expenditure tool and these notorious figures we called unforeseen expenses. This is ultra secret. In fact, all directors have in mind is reaching a given result [...]. You have so much shareholder pressure, and "I have to reach such and such a growth figure." Sometimes, if you have excellent earnings, you hide some intelligently. At $\mathrm{Z}$, each one of us does that within his branch, and afterwards you perform accounting operations that are completely legal.

(Media and Entertainment 2, Operational Management Controller)

For us-and I'm fairly sure it happens in most places-this over-exploitation of the "actual" is in line with the gradual decline of forecasting, due to pressure from the financial community. Since analysts expect a given result from me (benchmark versus competition, continued improvement, the holy grail of $15 \%$, etc.), why measure results using a internal budget, and not directly using this target figure?

The controller is less of a forecaster, and even less an analyst of shortfalls (the two traditional pillars of the profession, which we learn concretely about the job at school), but rather the one who will make it happen. The question is no longer "what am I capable of reaching?", followed by many revisions of the budget and the analysis of "why have I deviated in one direction, or another", but "how am I going to reach this goal?", i.e. my action plan, followed by "how am I going to reach it despite the deviations?"

[...] The additional ambiguity created by this shift is frightening. The title of co-pilot starts to take on its full meaning: we must land this plane in Buenos Aires by any means possible, and it is no longer acceptable to land in Stockholm with the excuse that the wind direction changed."

(Beverages, Zone Management Controller $\mathrm{N}^{\circ} 1$ )

It would therefore appear that shareholder pressure is exerted through control systems at all levels of an organisation, resulting in a rise in profit manipulation, in line with Merchant's findings (1990). What drives this profit manipulation is that in Anglo-Saxon corporate governance "things must happen as they were forecast" (Pesqueux, 2000, p.37) ${ }^{5}$ and this must be the case throughout the entire company. So, "the proliferation of transparency issues at all levels constitutes [...] a powerful relay reinforcing market pressure on how the company is steered" (Mottis \& Ponssard, 2002) ${ }^{6}$.

Moreover, with Anglo-Saxon corporate governance on the rise, the forecasting of financial goals is dictated by the financial markets before being considered at organisation level. We find ourselves in a situation of "disaggregating forecasts", which Berry and Otley (1975) present as encouraging profit manipulation. Our results confirm that "the widespread use of accounting information by investors and financial analysts to help value stocks can create an incentive for managers to manipulate earnings in an attempt to influence short-term stock price performance" (Healy and Wahlen, 1999, p.371). Arthur Levitt, SEC chairman in 1998, was already denouncing this phenomenon: "While the problem of earnings management is not new, it has swelled in a market that is unforgiving of companies that miss their estimates. I

\footnotetext{
${ }^{5}$ Indeed, many studies document that there are "an unusually large number of zeros and small positive forecast errors (cases where analyst forecasts are exactly met or just beaten) and an unusually small number of small negative forecast errors (near misses)" (Dechow and Skinner, 2000, p.243).

${ }^{6}$ Johnson and Kaplan (1987) show that in the United States external demands in terms of accounting documents have led to the use of control systems based on external accounting and therefore highlight the impact on internal control of the importance accorded to accounting in corporate governance.
} 
recently read of one major U.S. company that failed to meet its so-called "numbers" by one penny and lost more than six percent of its stock value in one day." Fox (1997) quoted the case of Microsoft corporation: "In January, for the $41^{\text {st }}$ time in the 42 quarters since it went public, Microsoft reported earnings that met or beat Wall Street estimates. The 36 brokerage analysts who make the estimates were, as a group, quite happy about this - the 57 cents per share announced by the software giant was above their consensus of 51 cents-but not so far above as to make them look stupid. Investors were happy too, bidding the already high-priced shares of the company up to $4 \%$ the first trading day after the announcement." This hysteria can be explained by the social links that binds actors: "This is the pattern earnings management creates: companies try to meet or beat Wall Street earnings projections in order to grow market capitalization and increase the value of stock options. Their ability to do this depends on achieving the earnings expectations of analysts. And analysts seek constant guidance from companies to frame those expectations. Auditors, who want to retain their clients, are under pressure not to stand in the way."

\section{Profit Manipulation by Management Controllers: from a Search for Legitimacy to Ethical Aspirations}

Why do management controllers take part in profit manipulation in a context of strong shareholder pressure? Two distinct types of behaviour come to the fore.

In companies with a relatively weak financial culture, profit manipulation is a way for management controllers to earn power and legitimacy with the operational managers they work with. It not only provides controllers recognition for their technical competence, often undervalued in the past, but also significantly increases the zone of uncertainty they can manage effectively, both in their relations with operational managers and with management control at headquarters.

In firms with a developed financial culture, profit manipulation is seen in the eyes of management controllers as an "ethical" stance, a solution to face the irrational dictate of the financial markets. Management controllers sense the dangers of an exclusively financial orientation (for themselves and for the company). In collaboration with operational managers, management controllers operate accounting adjustments to create room for manoeuvre for managers to achieve their strategic goals, without being systematically obsessed by "how their balance sheet looks". Performing profit manipulation appears in their eyes as a way of adopting a new role: that of arbiter between market expectations and business reality, sometimes going as far as telling operational managers to forget the figures in order to take more risks.

\section{Profit Manipulation and the Search for Legitimacy by Controllers}

As we have already mentioned, one of the underlying problems that controllers face is the ambiguity relating to their hierarchical and functional attachment (Bouquin, 2001). In theory, the management controller's position is clear: his mission is not to control, but to provide information and tools to help managers control and feed headquarters the necessary information for steering the company. In reality, the situation is quite different and the 
relationships rather more complex. In order to obtain information from distrusting operational managers, the management controller must demonstrate the added value he provides and build a relationship of confidence with managers. To highlight how real this need for legitimisation is, it is interesting to compare the vision of a director of management control and the experience of two subsidiary management controllers.

The second principle that governs our activity is the total immersion of management controllers in the various professions as well as in projects. So, for example, the director of manufacturing has his own management controller with a small team, each factory has a management control department, and it's the same for sales and the international entities. These teams report hierarchically to their boss and functionally to myself.

(Automobile and Parts 2, C.F.O.)

Both a Beverages and a Pharmaceutical and Biotechnology management controller give vivid illustrations of what relationship issues lie behind the hierarchical structure.

This situation is very ambiguous. My first choice is always not to break the link with the operational manager, otherwise you have to change jobs or else change positions, because it is either him or you who walks. But if you ever get to breaking point- "I disagree so much with what you are saying that I'm going to blow the whistle"-you fall into the last category. Thankfully, this doesn't happen very often. $[\ldots]$

If you just stay a controller-handling and looking at figures and, if it's not right, saying something-you will never win the operational managers' trust. They will always see you as a controller, and you will never quite understand the reality and the drivers of the business. [...]

That means you really have choices to make and convictions to apply.

(Beverages, Zone Management Controller $\mathrm{N}^{\circ} 1$ )

When the new boss of the BU arrived, the first week was hell, because he didn't say anything to us. So, I had to involve my superiors by saying, "It's not possible... this situation is not tenable." There was zero confidence, no involvement in meetings, no invitation, no information.

As soon as I entered his sphere of activity wearing my management controller hat... it was, "lock the doors, batten down the hatches". I was the cop who was going to cut all his budgets... So, I had to tell him, "Wait a minute, you don't understand". We are not here to stop you from working, on the contrary. We have a support function and we must exchange information.

(Pharmaceuticals and Biotechnology sector, Business Unit Controller)

Only one choice is open to the management controller looking to work in the right conditions: turn the operational manager into a strategic ally. Profit manipulation seems a good opportunity for the controller to show off his technical expertise (often voluntarily toned down in the past to distinguish 'controller' from 'accountant') and, as a result, to increase his power within the organisation (Crozier \& Friedberg, 1977) ${ }^{7}$.

Of course, you can move reserves from one year to the next... Well, let's say it's something you do fairly naturally because it also makes things easier for you [...]. You do it up to a certain point and then from time to time you tell yourself: "No, that's too much. I have to be careful."

Again, if you have relations based on trust with your operational superior, it's ok. If you don't have this kind of relationship_-you have to go and see him, saying, "No, wait, I'll go as far as here but no further. This reserve could be useful to the group for something else, to reinvest elsewhere, etc." In practice, he's going to agree with you because he knows that you are the one who wields the pen at the end

\footnotetext{
7 "The first major source of power involves possessing skills in a functional specialisation which is difficult to replace. The expert is the only one who has the know-how, the knowledge and experience of a given situation, which enable him to solve certain critical problems for the company. [...] Once the efficient running of an activity, a sector or an important function for the organisation depends on him, he will be able to negotiate for advantages or perks" (Crozier \& Friedberg, 1977, p.84).
} 
of the day. If he really doesn't agree, you're going to have to make a decision alone.... Since you have your network, you make a few phone calls off-the-record to spread the word, so that someone phones him up and asks, "Hey, if you happen to have lots of reserves, it would really help us out if you could free some of them up". You try to show a little political acumen in this situation, and if that doesn't work, at that point, you are forced to denounce your boss, which is never good. It's better to avoid doing that.

(Beverages, Zone Management Controller $N^{\circ} 2$ )

In companies where controllers traditionally lack legitimacy, the growing importance given to financial communication provides an opportunity to play a new role in the organisation. The controller becomes a "double borderline mover"-double marginal secant (Crozier \& Friedberg, 1977) ${ }^{8}$ - acting in the zone where the unit and headquarters cross, and where financial markets and the company meet.

\section{Profit Manipulation as an Ethical Act}

In companies with a developed financial culture, management controllers have perfect legitimacy. Nonetheless, the rise in shareholder pressure only serves to exacerbate the feeling amongst controllers that all the actors in a company only care about the accounting priorities of their activity. This raises the question of their own added value, in relation to operational managers who are totally under control because they only think in terms of ratios and bonuses. In this case, profit manipulation takes on a quasi-ethical aspect. On the one hand, perceiving the risk of financial drift in the company's long-term prospects, management controllers look to play an arbiter's role by managing earnings, leaving operational managers to do their work without being obsessed by the accounting point of view. On the other hand, they can play the role of counterweight to operational managers looking to take advantage of weaknesses in the compensation system.

The accounting viewpoint is: "the cost is this much, your budget is this much, you have spent that much". That's accounting. We have to do it. Well, we have to gather the information. But afterwards, it's all about perception when you say: "OK, what's important in this factory? What do we have to do? Where are our risks? How can we orientate things?"

[...] We have to be able to understand people's problems as well. We have to understand the factory's needs. If someone needs to spend 100,000 francs, and, as a result, will save 2 million, well, even if he overshoots his budget, you have to make a choice. We cannot be completely blinkered.

(Food producers and processors, Factory Management Controller)

You are in a situation where you know that a manager is passing off all his marketing expenses as sales expenditure-these are sections of the accounts that closely interact-because for him it is a way of increasing volume quickly. Seen from above, it's not because we are building brands or because it disrupts the market... Your own conviction will be somewhere in between: “OK, on the one hand, I have people who are technocrats. They think that if I do some advertising, everything will be fine, that I don't need to set sales targets. On the other side, I have salesmen who are looking to make

\footnotetext{
8 "The second major source of power we find in an organisation relates to all the uncertainties which develop around the relationship between the organisation and its environment [...] An organisation's "relevant environments", meaning the segments of society which the company is in contact with, always and inevitably constitute a source of potential disruption for its internal functioning, and, as such, a major and inescapable zone of uncertainty. Individuals or groups who, through their diverse contacts and capital of relations in such and such a segment of the environment, are able to control this zone of uncertainty, at least in part, will possess as a natural consequence considerable power within this zone. This power is called "double borderline mover" (double-marginal-sécant), meaning an actor who has a stake in several action systems in contact with each other and who, due to this fact, may play the indispensable role of intermediary and interpreter between the different, even contradictory, ways of doing things." (Crozier \& Friedberg, 1977, p.85).
} 
their lives easier, etc." You are going to manage your safety margin, by saying, “OK, it's fine up to here, I'll help and I'll even help to make sure it doesn't show too much." But there is a point when I have to alert my superiors. "We have done this, we think it is a good idea to have done it, but we prefer to inform you that it has been done." These situations are tremendously ambiguous.

(Beverages, Zone Management Controller $\mathrm{N}^{\circ} 1$ )

Moreover, the controller acquires a position as "arbiter" in relation to the various parties involved. They are a counterweight to totally opportunist behaviour that operational managers could show in a situation where the mechanisms of agency could possibly be biased.

Well, as for the legitimacy of the controller, I sometimes wonder... In marketing, they have astonishing bonuses based on results. As a consequence, they ask you on tenterhooks whether they are on track for their earnings target... You are on the sidelines, unflustered: "No, well $\boldsymbol{I}$ don't have a bonus... What interests me is that the figures hold water, I don't care about your bonus". It's really rotten to the core at that level. It's certainly a incentive, but it drives people to unhealthy behaviour... I've begun to realise this and it bugs me...

(Media and Entertainment 2, Operational Management Controller)

In companies with a strong management culture, management drift resulting from bonus systems in particular is frowned upon by controllers.

I think that they all have a financial culture. Marketers are focused on their margins, logisticians on respecting their budgets, but this financial culture should not be allowed to take centre stage. Because we thrive thanks to marketing, I agree the financial culture must be very present, but it should remain secondary for operational managers. That's not their job to know what their margin is. They must develop their markets, they must launch new products, they must have the backing of innovation, etc. $\mathbf{X}$ is about brands and developing markets.

(Food producers and processors, Operational Management Controller)

When we have had enough financial culture, and we realise that we are suffocating brands to release bigger margins and are not developing markets, we will come back to market development. [...] We will always need to generate profitability for shareholders, but in the short-term we can't afford to have that vision alone!

(Food producers and processors, Business Unit Management Controller)

Management controllers are fairly critical of operational managers' financial obsession. They realise the short-term vision that the bonus game fosters, and feel compelled to take on a counterweight role in the organisation.

This counterweight role is to be found in balancing the board's strategic decisions and their feasibility on the shop floor. When these decisions seem unreasonable or illegitimate, controllers seem ready to play an arbiter's role, notably by performing profit manipulation. This is behaviour that they implicitly present to themselves as being ethical.

This may seem surprising: this act cannot be considered as ethical from a universal point of view because profit manipulation prevents high-level managers and shareholders from allocating resources in the best possible way. However, management controllers present this behaviour as ethical in the struggle they are leading against shareholders and head office. As such, "profit manipulation is a morally justifiable means of resisting the oppression and exploitation pressed on them by upper executives using management accounting systems as a major vehicle." (Macintosh, 1995, p.306). It is a way to "clear some space and breathing room between the business component and the injunctions of upper level executives" (Macintosh, 1995, p.306). 


\section{Profit Manipulation: Different Incentives for Different Contexts}

The interviews that we conducted have enabled us to identify several earnings management policies by controllers.

The two axes for these different policies seem to be shareholder pressure and the spread of a financial culture. Our second axis deals with the respective power of financiers and engineers (or operatives) in managing the companies concerned and the spread of the financial culture within the firm. From these two axes, four situations can be identified.

\section{<Insert Figure 1 Here >}

\section{<Insert Table 4 Here>}

On the whole, companies of configuration 1 are either in the public sector or in a monopolistic position. With a view to the opening of their markets in the medium term, these companies have their own management control departments, but the political will to impose a financial orientation on the organisation is not yet strong. Management controllers are seen as "cops", and their added value remains hard for operational managers to see. In these companies, no controller mentioned any attempt at managing earnings.

Configuration 2 encompasses companies whose dominant culture is also technical, but which bear high shareholder pressure. In all these companies, management controllers mention profit manipulation as a common practice. Some speak more cautiously of "work on presentation". However, earnings management does not always take place at the same level. In highly capital-intensive companies, where investment decisions are always long-term and condition earnings to a large extent, most profit manipulation is conducted at central headquarters. In companies where marketing plays a major role, profit manipulation is performed at the level of the business units. In those companies with a more technical culture, earnings management by management controllers presents an opportunity for them to legitimate themselves with operational managers. It's an opportunity for them to show their technical skills in accounting, to integrate more easily into the "operational life" of the unit and to manage far greater zones of uncertainty.

In companies of configuration 3, management control is a concern shared by all. Operational managers and sometimes even management controllers are subject to remuneration systems tied to reaching their objectives. The presence of controllers is therefore completely legitimate and earnings management is conducted at all levels. Nonetheless, the incentives driving controllers are very different here. Heavily involved in the daily operations of the unit, they sometimes perceive the market's demands as unreasonable, and the company's uniquely financial focus as a potential danger in the long term. Profit manipulation presents itself as a means for management controllers to play the role of counterweight, by according operational managers a certain margin for manoeuvre to implement more risky strategies or strategies whose return on investment is far more long term than what the market's shortsightedness would normally allow.

None of the companies in our sample seem to correspond to configuration 4. Several explanations are possible. Since the configuration is less common, we were not led to meet a 
company that corresponded, given the small scale of our sample. We can also presume that companies not subject to shareholder pressure have no reason to develop a financial culture from within. Another option is that it is highly unlikely that companies with a strong financial culture will not be highly visible on the markets.

From our observation of the spread of the Anglo-Saxon corporate governance model and from what management controllers are saying, we can propose a model explaining profit manipulation.

\section{<Insert Figure 2 Here>}

\section{How Valid is the Agency Model in a French context?}

Our empirical data enables us to draw a certain number of theoretical findings, firstly on the validity of the agency model as a basis for governance in a French cultural context. Profit manipulation performed by management controllers must be put in perspective. The AngloSaxon model of corporate governance is consistent with a specific cultural context, and lends factual data, and therefore accounts, a special status. Indeed, the American approach to collecting and handling factual data is intimately tied to the American way of life. Judicial or quasi-judicial procedures, which are held in high esteem, give fundamental value to material proof. The way data is collected and used reflects the American preference for accounts that everyone should render public (d'Iribarne, 1989, p.103). Accounting statements correspond perfectly to this way of thinking.

The French distinguish two roles factual data is likely to play: enabling us to understand better how things work; and providing a means of assessing people. In the French system, confusing these two roles (which is perfectly legitimate in the United States) generates resistance. The controller's sense of responsibility alone (meaning what he feels responsible for, and not what he needs to account for) makes him pay attention to information he receives. The French model hardly encourages us to judge each person on the basis of such data and is opposed to superiors demanding accounts that are too stringent. That subordinates may protect themselves from all hierarchical "interference" by surrounding their activity in a shroud of opacity is not considered an illegitimate act.

As a consequence, it is the legitimacy of accounts that lies at the heart of the debate in a French context. In general, accounts can be seen as perfectly legitimate by an individual, when they are only seen as signals enabling him to see clearly the direct and indirect consequences of his actions, leaving him room to draw his own conclusions. Such an approach seems well adapted to the way one's sense of duty is expressed in French society. It is expected that accounts would encourage stakeholders in their actions to take into account what a narrow-minded or short-term vision of their responsibilities would lead them to neglect (d'Iribarne, 1989, p.106).

In the Anglo-Saxon model of governance, accounts are part of a conception, which completely opposes what would most likely be accepted in France. Designed as strictly financial instruments and short-term assessment criteria, they lose all legitimacy. Since 
factual data in France has no sacred value, changing or inventing it does not constitute a major transgression. From that point on, manipulating accounts seems to be an ethical practice, almost natural, an act so anchored in everyday values that individuals may not even be aware of it.

\section{Questioning the Relevance of Positive Accounting Theory}

Positive accounting theory (PAT), which studies accounting choices, has been overly interested in earnings management. Despite this attention, "academic research has shown limited evidence of earnings management" (Dechow and Skinner, 2000, p.235). This lack of evidence leads us to question the relevance of PAT. Nevertheless, we do not try to consider all the numerous methodological, theoretical and epistemological criticisms that have been levelled against PAT $^{9}$. Instead, we focus on two points: the methodology chosen, and the "model of man."

Positive accounting theory positions itself in an objective perspective which consists in discerning earnings management from accounting documents, and checking the validity of economic hypotheses formulated on the behaviour of managers regarding earnings management. This methodological choice is relatively incongruous for a field of research, which in the words of Watts and Zimmerman (1990, p.147) is in an "exploratory stage".

Moreover, PAT researchers examine large samples of firms to make general statements about earnings management. Dechow and Skinner (2000, p.236) argue that researchers "tend to use statistical definition of earnings management that may not be very powerful in identifying earnings management", and conclude that "the current research methodologies simply are not that good at identifying earnings management".

Dealing with the model of actors, Watts and Zimmerman (1990, p.150) assert that, "the study of accounting is a social science. An accounting theory that seeks to explain and predict accounting cannot divorce accounting research from the study of people. The contracting approach to studying accounting requires researchers to understand the incentives of contracting parties." However, they hold to a fairly summary economic and opportunist modelling of manager behaviour based on the network of contracts which a manager is involved in. They add that "the [positive accounting] literature explains why accounting is used and provides a framework for predicting accounting choices, [...] choices are made in terms of individual objectives and the effects of accounting methods on the achievement of those objectives." (Watts \& Zimmerman, 1990, p.150).

Nevertheless, if explaining opportunist behaviour ex-post seems straightforward, predicting it ex-ante is difficult. Like the agency theory, PAT relies on the model of a rational actor who looks to optimise his utility at any given moment in time (Merchant et al., 2003, p.271). Both theories postulate that agents always display opportunistic behaviour. This model claims to reflect relationships between shareholders and directors, and managers and workers objectively (Chwastiak, 1998, p.428). However, the rationality and utilitarianism hypotheses on which it lies are reflections of ideological presuppositions to a large extent (Broadbent et al., 1996). Aren't agency theoreticians victims of "scholastic fallacy" by portraying man as a

\footnotetext{
${ }^{9}$ A radical critique of PAT can be found in Tinker et al. (1982).
} 
rational calculator in all situations (Bourdieu, 1994, p.222)? ${ }^{10}$ Whilst studying the social realm can only be achieved by considering that "social agents don't just do any old thing, that they are not mad, and that they don't act without purpose" (Bourdieu, 1994, p.150), this doesn't necessarily mean they are opportunists. "Practice has a logic which isn't that of logic and, as a result, applying logical logic to practical logic is to risk destroying, with the instrument we are using to describe it, the logic we want to describe" (Bourdieu, 1994, p.157). To avoid this pitfall, we have sought to understand practices, to find the reasons that drive people to act as they do. We have noted that management controllers give reasons for manipulating profits that differ according to their position: a search for legitimacy or an ethical stance. We cannot therefore reduce this behaviour to the level of opportunism as put forward by PAT.

Trying to predict behaviour without trying to understand it is an illusion. This way of modelling behaviour therefore teaches us very little about what drives the behaviour of accounting decision-makers. These critics question Watt and Zimmerman's argument about theory validity ${ }^{11}$. Does the PAT acceptance and use by the scientific community necessarily imply its validity? Is this not simply the shadow of economic imperialism passing over the field of accounting research (Reiter, 1988)?

\section{The Paradoxical Place of Accounting Information in the Anglo-Saxon Model of Corporate Governance}

This study sheds light on the internal contradictions of the principal-agent model, and particularly on the paradoxical place that accounting data holds in this model. The standards of Anglo-Saxon governance lead to the model of contractual relationships presented in agency theory being applied (Davis \& Useem, 2002, p.236). Agency theory postulates that, in an agency situation, if the interests of the agent differ from those of the principal, the agent will display opportunist behaviour to the detriment of the principal. This must be solved by establishing incentive systems that bring the interests of the agent into line with those of the principal. This is why accounting plays a key role in the Anglo-Saxon model of governance (Ogden, 1993, p.185).

Despite its weaknesses, the ideological force of the agency model has allowed it to spread through different cultural models. Our interviews show that the widespread adoption of the Anglo-Saxon model of corporate governance in French companies (and, as a result, of the contracting relationship and accounting mode that is associated with it) is leading to a rise in the practice of profit manipulation by management controllers ${ }^{12}$. In the Anglo-Saxon model of

\footnotetext{
${ }^{10}$ With this in mind, we may question what is the real contribution of theoretical and analytical literature (for an example, see studies by Dutta \& Gigler, 2002 and Kirschenheiter \& Melumad, 2002)

${ }^{11}$ Indeed, what better way to respond to criticism than by saying, "the criticisms have failed because they have had little influence on accounting research" (Watts \& Zimmerman, 1990, p.149) and by adding that "the best theory is determined in a competition to meet the demand from students and practitioners for theories that explain and predict accounting" (Watts \& Zimmerman, 1990, p.150).

12 Profit manipulation is considered an opportunist practice in PAT, which engenders the following paradox: the more agency theoreticians succeed in imposing an organisational model which is optimal in the context of agency theory (i.e. with "contractual accountability" rather than "communal accountability", Broadbent et al,
} 
governance, accounting is both an input into the system (because it enables agency relationships to be managed), and an output (because it relies on measures of institutional governance working) (Sloan, 2001). As such, accounting fulfils several functions (forecasting, resources allocation, control, and personal appraisal) and these various issues conspire to reduce its reliability. This creates the following paradox: the more accounting is necessary for governance, the less the information it provides is relevant.

These results lead us to investigate the risks associated with profit manipulation. Indeed, "most people think that earnings management is a bad thing because [...] it reduces the relevance of financial information" (Scott, 1997, p.307). However, to a certain extent, profit manipulation seems to fulfil a necessary role in the efficient running of companies in an Anglo-Saxon corporate governance context. As we have pointed out, it may even take on an ethical nature. It ensures that risks may be taken which are necessary for economic activity without discrediting high-level management.

This confirms Dechow and Skinner's (2000, p.247) affirmation that "no earnings management is clearly not an optimal solution." Some earnings management is expected and should exist on capital markets."

1996), the more tenants of PAT feel that accounting choices result from opportunist behaviour and the more their theoretical supposition (the opportunism of agents) seems to reflect real behaviour. 


\section{Conclusion}

In this article, we have proposed an interpretation of the practice of profit manipulation based on interviews with thirty-two management controllers from thirteen different companies.

One major factor that explains this phenomenon emerges from our interviews: the shift in corporate governance and the rise in shareholder pressure that accompanies it. In companies with a weak financial culture, changes in the rules of the game relating to increased shareholder pressure give management controllers the opportunity, given their technical know-how, to strengthen their legitimacy with operational managers by helping them to manipulate profit. In companies with a developed financial culture, management controllers feel the dangers of an exclusively financial focus. Taking part in profit manipulation is one way of playing a new role: that of arbiter between the expectations of the markets and the actual business context. Dechow and Skinner (2000) criticise academic studies for having accorded too much importance to "contractual incentives" to the detriment of "capital markets incentives" in studying profit manipulation. Our research leads us to believe, however, that these two forms of incentive are very often intrinsically linked.

From a more distant perspective, we may ask whether or not, before adding another layer of legislation on governance, we should question the validity of the theoretical model that underlies it (Batsch, 2002). Some commentators even believe in the "End of History, that is to say the definitive supremacy of the Anglo-Saxon model of governance, but recent scandals force us to think about alternative models (Perez, 2003).

Thus, Davis and Useem (2002, p.233) affirm that "earnest attempts to meet the demands of shareholders for transparency and accountability, as prescribed by the agency theory of governance, often have unintended consequences. Firms that improve the quality of their disclosures attract more transient institutional investors, which in turn increases the volatility of their share prices -exactly the opposite of what was anticipated." In the same way, we may ask if the spread of Anglo-Saxon practices of governance in countries that do not follow the same cultural patterns, especially those that have a different approach to contracting (d'Iribarne, 1989), may not have unexpected consequences, resulting in the multiplication of profit manipulation practices at all levels and reducing the relevance of financial statements at the very moment that they are becoming the principle mechanism of governance.

\section{Acknowledgments}

Both authors are especially grateful to Henri Bouquin for his ongoing comments, and the very helpful comments of the referee. We appreciated comments from participants at the 2003 EAA Congress and the 2003 AFC Congress. We also thank the FNEGE and CEFAG programs. 


\section{References}

Anthony, R.N., The Management Control Function (Boston: The Harvard Business School Press, 1988)

Anthony, R.N., Govindarajan V., Management Control Systems (New York, Mac Graw Hill 10 ${ }^{\text {th }}$ ed., 2001)

Arnold, M., “Companies and markets : SEC investigating Alstom's US unit, Financial Times, USA ed., July 1st, 2003, p. 17

Baiman, S., "Agency Research in Managerial Accounting: A Second Look, Accounting, Organizations and Society, 1990, pp. 341-371

Barr, S., "Misreporting results", CFO.com, Dec 1st, 1998, pp 37-48

Batsch, L., Le capitalisme financier (Repères, Col. La Découverte, Paris, 2002)

Berry, A., Otley, D. "The aggregation of estimates in hierarchical organization", The Journal of Management Studies, may, 1975, pp. 175-193.

Bouquin, H., Le contrôle de gestion (Paris: PUF, Collection "Gestion", 5ème éd., 2001)

Bourdieu, P, Raisons pratiques: sur la théorie de l'action, (Paris: Seuil, 1994)

Broadbent, J., Dietrich, M., Laughlin, R., "The development of principal-agent, contracting and accountability relationships in the public sector: conceptual and cultural problems", Critical Perspectives on Accounting, Vol. 7, 3, 1996, pp. 259-284.

Busham, R.M. Smith, A.J., "Financial accounting information and corporate governance", Journal of Accounting and Economics, 32, 2001, pp. 237-333.

Byrnes, N., Melcher, R.A., Sparks, D., "Earnings Hocus-Pocus”, Business Week, October 5 ${ }^{\text {th }}$, 1998, pp.134-142

Chwastiak, M., "Deconstructing the principal-agent model: a view from the bottom", Critical Perspectives on Accounting, Vol. 10, Issue 4, 1999, pp. 425-441.

Colasse, B., “Auditer, une mission impossible?”, Sociétal, vol. 39, 2003, pp. 38-39.

Collingwood, H., “The Earnings Game, Everyone Plays, Nobody Wins”, Harvard Business Review, June 2001, pp.65-74.

Copeland, R.M., "Income smoothing", Journal of Accounting Research, Empirical Research in Accounting, Selected Studies 6 (Supplement), 1968, pp. 101-116.

Crozier, M., Friedberg, E., L'acteur et le système, (Coll. Points Seuil, Paris, 1977)

Davis, G.F., Useem, M., "Top management, Company directors and Corporate control", in Handbook of strategy and management, ed. A. Pettigrew, H Thomas, R. Whittington, 2002, pp. 232-258.

Dechow, P., Sloan, R., Sweeney, A., "Detecting earnings management ”, The Accounting Review 70(2) 1995, pp. 193-225.

Dechow, P., Skinner, D.J., "Earnings Management: Reconciling the Views of Accounting Academics, Practitioners, and Regulators", Accounting Horizons, vol.14, 2, 2000, pp.235-250

Dutta, S., Gigler, F., "The Effect of Earnings Forecasts on Earnings Management", Journal of Accounting Research, Vol.40, N³, June 2002, pp. 631-655

Fay, S., "Deux dirigeants d'Altran démissionnent après la confirmation d'irrégularités comptables", Le Monde, April 29, 2003, p.32

Fligstein, N., The transformation of corporate control (Boston: Harvard University Press, 1990)

Fligstein, N, "The politics of quantification", Accounting Organization and Society, vol.23, 3, 1998, pp. 325333.

Fox, J., "Learn to play the earnings game (and Wall Street will love you)", Fortune, New York, Mar 31st, 1997, pp. $76-80$

Guidry, F., Leone, A., Rock, S., "Earnings-based bonus plans and earnings management by business-unit managers", Journal of Accounting and Economics, 26(1-3), January 1999, pp. 113-142. 
Gibbins, M., "Discussion of Evidence from Auditors about Manager's and Auditor's Earnings Management Decisions", The Accounting Review, Vol.77, Supp., 2002, pp.203-211

Healy, P.M., Walhen, J.M., "A Review of the Earnings Management Literature and Its Implications for Standard Setting”, Accounting Horizons, vol.13, 4, 1999, pp. 365-383

Henry, D., Schmitt, C.H., “The Numbers Game”, Business Week, May 14 ${ }^{\text {th }}$, 2001, pp. 100-110

Iribarne (d'), P., La logique de l'honneur, (Paris éd. Points Seuil, 1989)

Jeffers, E., Plihon, D., "Importance et diversité des investisseurs institutionnels", in La montée en puissance des fonds d'investissement, eds D.Plihon and J.P. Ponssard, Les études de la documentation Française, 2002

Jeffers, E., Magnier, V., "Le gouvernement d'entreprise et les FIE au niveau international" in La montée en puissance des fonds d'investissement, eds. D.Plihon and J.P. Ponssard, Les études de la documentation Française, 2002

Johnson, H.T., Kaplan, R.S., Relevance Lost, The Rise and the Fall of Management Accounting (Harvard Business School Press, 1987)

Kirschenheiter, M., Melumad, N.D., "Can 'Big Bath' and Earnings Smoothing Co-exist as Equilibrium Financial Reporting Strategies?”, Journal of Accounting Research, Vol.40, N3, June 2002, pp. 761-796

Levitt, A., Remarks by Chairman Arthur Levitt, "The Number Game", 1998, http://www.sec.gov/news/speech/speecharchive/1998/spch220.txt

Lejoux, C., "Marionnaud tente de clarifier sa comptabilité", La Tribune Desfossés, 30 avril 2003

Macintosh, N. B., "The Ethics of profit manipulation: A Dialectic of Control Analysis", Critical Perspectives on Accounting, Vol.4, N 4,1995 , pp. 289-315.

Merchant, K.A., "The Effects of Financial Controls on Data Manipulation and Management Myopia", Accounting, Organizations and Society, Vol.15, N4, 1990, pp.297-313

Merchant, K.A., Van der Stede, W.A., Zheng, L., "Disciplinary Constraints on the Advancement of Knowledge: the Case of Organizational Incentive Systems”, Accounting, Organizations and Society, Vol. 28, `2-3, 2003, pp.251-286

Mintzberg, H., Power In and Around Organizations (Englewood Cliffs, N.J.: Prentice Hall, 1983)

Moriceau, J.L, Villette, M., "L'EVA, le contrôle et...le fil qui hante", Expansion Management Review, sept., 2001, pp. 96-102.

Mottis, N., Ponssard, J.P., "L'impact des FIE sur le pilotage de l'entreprise", in La montée en puissance des fonds d'investissement", eds. D. Plihon and J.P. Ponssard, Les études de la documentation Française, 2002.

Nelson, M.W., Elliott J.A., and Tarpley R.L.,"Evidence from Auditors about Manager's and Auditor's Earnings Management Decisions”, The Accounting Review, Vol.77, Supp., 2002, pp.203-211

Ogden, S. G., "The Limitations of Agency Theory: The Case of Accounting-Based Profit Sharing Schemes", Critical Perspectives on Accounting, Vol. 4, Issue 2, 1993, pp. 179-206.

Orange, M., " Les actionnaires ne connaîtront pas de sitôt les causes de leur ruine”, Le Monde, 3 July 2003, p.18

Perez, R., La gouvernance de l'entreprise (Repères, Col. La Découverte, Paris, 2003)

Pesqueux, Y., Le gouvernement d'entreprise comme idéologie, (Paris: Ellipses, 2000).

Reiter, S. A., "Economic imperialism and the crisis in financial accounting research", Critical Perspectives on Accounting, Vol.9, $\mathrm{N}^{\circ} 2,1998$, pp. 143-171.

Richard, C., Reix, R., "Contribution à l'analyse de la qualité du processus d'audit : le rôle de la relation entre le directeur financier et le commissaire aux comptes", Comptabilité-Contrôle-Audit, Tome 8, Vol.1, May 2002, pp.151-174

Ronen, J., Sadan, S.et Snow, C., "Income smoothing: A review", Accounting Journal, Spring, 1977, pp. 11-26.

Schipper, K., "Commentary on Earnings management", Accounting Horizons, vol.3, 4, Dec, 1989, pp. 91-102.

Scott, W., Financial accounting theory, (Englewood Cliffs, N.J.: Prentice Hall, 1997) 
Shleifer, A., Vishny, R.W., "A survey for corporate finance”, The Journal of Finance, vol.52,.2, 1997, pp. 737784.

Simon, H.A., et al., " Organizing for Controllership: Centralization and Decentralization ", The Controller, vol. 33, pp.11-13, 1955, copyright by the Financial Executives Institute.

Sloan, R.G., "Financial accounting and corporate governance: a discussion", Journal of Accounting and Economics, vol. 32, 2001, pp. $335-347$

Stolowy, H, Breton, G, "A framework for the classification of accounts manipulations", Cahier de recherche HEC, 2000.

Thiery-Dubuisson, S., "Exigences actionnariales et réseaux d'administrateurs : A quoi répond la mise en place des comités d'audit en France“, Comptabilité-Contrôle-Audit, Tome 8, Vol.1, May 2002, pp.129-150

Tinker, A.M., "Toward a Political Economy of Accounting: an empirical illustration of the Cambridge controversies", Accounting, Organizations and Society, Vol.5, $\mathrm{N}^{\circ} 1$ 1, 1980, pp.147-160

Tinker, A.M., Merino B., Neimark, M.D., "The Normative Origins of Positive Theories: Ideology and Accounting Thought”, Accopunting, Organizations and Society, Vol.7, N’2, 1982, pp.167-200.

Watts, R., Zimmerman, J., "Positive accounting theory: a ten year perspective", The Accounting Review, vol. 65, 1990, pp. 131-156. 


\begin{tabular}{|c|c|c|c|}
\hline ACCOUNTING CHOICES & DEFINITIONS $^{13}$ & U.S. CASES & FRENCH CASES \\
\hline \multicolumn{4}{|c|}{ Within Accounting Standards } \\
\hline \multicolumn{4}{|l|}{$\begin{array}{c}\text { Overly aggressive recognition } \\
\text { of provisions or reserves }\end{array}$} \\
\hline $\begin{array}{l}\text { MERGER MAGIC } \\
\text { Overevaluation of acquired in- } \\
\text { process R\&D in purchase } \\
\text { acquisitions }\end{array}$ & $\begin{array}{l}\text { Whole industries have been remade through } \\
\text { consolidations, acquisitions and spin-offs. Some } \\
\text { companies have no choice but to use purchase accounting } \\
\text { - which can result in lower future earnings. But that's a } \\
\text { result some companies are unwilling to tolerate. So what } \\
\text { do they do? They classify an ever-growing portion of the } \\
\text { acquisition price as "in-process" Research and } \\
\text { Development, so the amount can be written off in a "one- } \\
\text { time" charge - removing any future earnings drag. }\end{array}$ & $\begin{array}{l}\text { "Multibillion-dollar charges [were] taken } \\
\text { by high-tech acquirers such as Compaq } \\
\text { Computer Corp. and WorldCom Inc. to } \\
\text { write off "in-process" research when they } \\
\text { close a deal." (Byrnes et. al, 1998) }\end{array}$ & \\
\hline $\begin{array}{c}\text { BIG BATH } \\
\text { RESTRUCTURING CHARGES } \\
\text { Overstatement of restructuring } \\
\text { charges and asset write-offs }\end{array}$ & $\begin{array}{l}\text { Companies remain competitive by regularly assessing the } \\
\text { efficiency and profitability of their operations. Problems } \\
\text { arise, however, when we see large charges associated with } \\
\text { companies' restructuring. These charges help companies } \\
\text { "clean up" their balance sheet -- giving them a so-called } \\
\text { "big bath." }\end{array}$ & $\begin{array}{l}\text { "In March 1998, the SEC compelled the } \\
\text { company [3 Com] to reduce its } \\
\text { restructuring charge for the } 1997 \text { purchase } \\
\text { of U.S. Robotics Corp to } \$ 279 \text { million } \\
\text { from } \$ 426 \text { million, because } 3 \text { Com had } \\
\text { overestimated the associated expenses." } \\
\text { (Barr, 1998). }\end{array}$ & \\
\hline \multicolumn{4}{|l|}{$\begin{array}{c}\text { Earnings that result from a } \\
\text { neutral operation of the process }\end{array}$} \\
\hline $\begin{array}{l}\text { Understatement of the } \\
\text { provision for bad debt and } \\
\text { drawing down provisions or } \\
\text { reserves in an overly } \\
\text { aggressive manner }\end{array}$ & & & $\begin{array}{l}\text { "Alstom, the French engineering } \\
\text { group had discovered } \\
\text { "significantly understated losses" } \\
\text { on a railway carriage contract at its } \\
\text { US transport subsidiary which had } \\
\text { forced it to take a Euros } 51 \mathrm{~m} \\
\text { (Dollars 58m) charge." (Arnold, } \\
2003 \text { ) }\end{array}$ \\
\hline
\end{tabular}

Table 1 - Practices of Earnings Management

Adapted from Dechow \&Skinner (2000) and Levitt (1998)

${ }^{13}$ These definitions were proposed by former SEC Chairman Arthur Levitt (1998) 


\begin{tabular}{|c|c|c|c|}
\hline \multicolumn{4}{|c|}{ Violates Accounting Standards } \\
\hline ACCOUNTING CHOICES & DEFINITIONS $^{14}$ & U.S. CASES & FRENCH CASES \\
\hline IMMATERIAL MISAPPLICATION & $\begin{array}{l}\text { Some companies misuse the concept of materiality. } \\
\text { They intentionally record errors within a defined } \\
\text { percentage ceiling. They then try to excuse that fib } \\
\text { by arguing that the effect on the bottom line is too } \\
\text { small to matter. }\end{array}$ & & \\
\hline $\begin{array}{l}\text { PREMATURE RECOGNITION OF } \\
\text { REVENUE } \\
\text { Recording sales before they are } \\
\text { "realizable" }\end{array}$ & $\begin{array}{l}\text { Some companies are recognizing a revenue before a } \\
\text { sale is complete, before the product is delivered to a } \\
\text { customer, or at a time when the customer still has } \\
\text { options to terminate, void or delay the sale. }\end{array}$ & $\begin{array}{l}\text { "MicroStrategy Inc. reported revenue in three } \\
\text { quarters in } 1998 \text { and } 1999 \text { based on contracts } \\
\text { it did not complete until after the quarters had } \\
\text { ended, the SEC found." (Henry, Schmitt, } \\
\text { 2001) }\end{array}$ & \\
\hline Recording fictitious sales & & & $\begin{array}{l}\text { "Altran Technologies had to reduce its } \\
\text { former reported revenue by } 48 \% \text { for } \\
\text { the first quarter because of fictitious } \\
\text { and atypical sales." (Fay, 2003) }\end{array}$ \\
\hline \multicolumn{4}{|l|}{ Backdating sales invoices } \\
\hline $\begin{array}{l}\text { Overstating inventory by } \\
\text { recording fictitious inventory }\end{array}$ & & & $\begin{array}{l}\text { "Marionnaud confessed an error about } \\
\text { evaluating inventory, that had } \\
\text { increased its } 2001 \text { EBIT by } € 2.5 \\
\text { million". (Lejoux, 2003) }\end{array}$ \\
\hline
\end{tabular}

Table 1 (continued-1)- Practices of Earnings Management

Adapted from Dechow \&Skinner (2000) and Levitt (1998)

${ }^{14}$ These definitions were proposed by former SEC Chairman Arthur Levitt (1998) 


\begin{tabular}{|c|c|c|c|}
\hline $\begin{array}{c}\text { "REAL" CASH FLOW } \\
\text { CHOICES }\end{array}$ & DEFINITIONS & U.S. ILLUSTRATIONS & FRENCH ILLUSTRATIONS \\
\hline $\begin{array}{l}\text { COOKIE JAR RESERVES } \\
\text { Delaying sales }\end{array}$ & $\begin{array}{l}\text { Using unrealistic assumptions to estimate liabilities for } \\
\text { such items as sales returns, loan losses or warranty costs. } \\
\text { In doing so, companies stash accruals in cookie jars during } \\
\text { the good times and reach into them when needed in the } \\
\text { bad times. }\end{array}$ & & \\
\hline \multicolumn{4}{|l|}{$\begin{array}{c}\text { Accelerating / Postponing R\&D } \\
\text { or advertising expenditures }\end{array}$} \\
\hline $\begin{array}{l}\text { CHANNEL STUFFING } \\
\text { Accelerating sales }\end{array}$ & $\begin{array}{l}\text { Selling goods to customers who aren't ready to buy yet. } \\
\text { To make the deal attractive to the buyer, the seller often } \\
\text { finances the purchase interest free and, in some cases, } \\
\text { picks up the cost of storing the goods until the customer } \\
\text { is ready to take delivery (Collingwood, 2001). }\end{array}$ & $\begin{array}{l}\text { In order to post the earnings gains that } \\
\text { supported the price of Sunbeam's } \\
\text { stock, Dunlop sold millions of dollars } \\
\text { worth of backyard grills to customers } \\
\text { like Sears and Wal-Mart in the middle } \\
\text { of, the Winter.[...]. Sunbeam booked } \\
\text { the sales immediately but let its } \\
\text { customers defer payment until the } \\
\text { Spring. (Collingwood, 2001) }\end{array}$ & \\
\hline
\end{tabular}

Table 1 (continued-2)- Practices of Earnings Management

Adapted from Dechow \&Skinner (2000) and Levitt (1998) 


\begin{tabular}{|c|c|c|c|c|c|c|c|}
\hline \multirow{2}{*}{$\begin{array}{c}\text { SECTORS } \\
\text { (FTSE }^{\text {TM }} \text { Global Classification } \\
\text { System) }\end{array}$} & \multicolumn{3}{|c|}{ Head Office } & \multicolumn{4}{|c|}{ Business Units } \\
\hline & C.F.O. & $\begin{array}{l}\text { Zone/ } \\
\text { Branch }\end{array}$ & $\begin{array}{l}\text { Reporting/ } \\
\text { budgetary }\end{array}$ & C.F.O. & $\begin{array}{c}\text { Factory } \\
\text { Controller }\end{array}$ & $\begin{array}{l}\text { Operational } \\
\text { Controller }\end{array}$ & $\begin{array}{l}\text { Budgetary } \\
\text { Controller }\end{array}$ \\
\hline Mining & 1 & & & & & & \\
\hline Oil and Gas & & 2 & & & & & \\
\hline Steel and other metals & 1 & & & & & & \\
\hline Automobile and Parts 1 & & & & & 1 & & \\
\hline Automobile and Parts 2 & 1 & & & 1 & & & \\
\hline Beverages & & 2 & & & & & \\
\hline Food producers and processors & & & & 1 & 1 & 5 & 1 \\
\hline $\begin{array}{l}\text { Personal Care and Household } \\
\text { products } \\
\end{array}$ & & & 1 & 1 & & 4 & 1 \\
\hline Pharmaceuticals and Biotechnology & & & & & & 1 & \\
\hline Media and Entertainment 1 & & & & & & 1 & \\
\hline Media and Entertainment 2 & & & & & & 1 & \\
\hline Transport & 1 & & 1 & & & 2 & \\
\hline Utilities & & 1 & & & & & \\
\hline
\end{tabular}

Table 2 - Interview Population 


\begin{tabular}{|c|c|}
\hline PRACTICES & EXAMPLES \\
\hline $\begin{array}{l}\text { HIDING REVENUES } \\
\text { COOKIE JAR RESERVES }\end{array}$ & $\begin{array}{l}\text { "You find yourself with a really super month of December, } \\
\text { or you've kept reserves all over the place-the rule is } 60 / 40 \text {, } \\
\text { which means you always try to have at least a } 60 \% \text { chance } \\
\text { of reaching your target and a } 40 \% \text { risk of not reaching it, so } \\
\text { you stash reserves all over-or it just so happens sales have } \\
\text { been very good, so you find yourself with loads of reserves. } \\
\text { What you generally try and do then-and all management } \\
\text { controllers will tell you the same thing-is not to disclose } \\
\text { this fact, but to keep the jackpot for the following year. } \\
\text { Well, let's say that it's something you conform to fairly } \\
\text { naturally because it also makes it easier for you to pilot } \\
\text { things and everything remains vague. What is the real } \\
\text { result? What is the official result? Etc." } \\
\text { (Beverages, Zone Operational Management Controller } \mathrm{N}^{\circ} 1 \text { ) }\end{array}$ \\
\hline $\begin{array}{c}\text { CREATING CHARGES } \\
\text { Accelerating R\&D or advertising } \\
\text { expenditures }\end{array}$ & $\begin{array}{l}\text { "It could be a question of 'lumping } 100 \% \text { of advertising costs } \\
\text { together at the end of the year'. For us, the accounting } \\
\text { principle is to amortise your advertising. But if a collection } \\
\text { goes badly, we do not amortise it, we account for it } 100 \% \text {. } \\
\text { This will make your result slump." } \\
\text { (Media and Entertainment 2, Operational Management } \\
\text { Controller) }\end{array}$ \\
\hline $\begin{array}{l}\text { INCREASING CHARGES } \\
\text { Overly aggressive recognition of } \\
\text { provisions or reserves }\end{array}$ & $\begin{array}{l}\text { "Amortisation is very heavy. This is a capital-intensive } \\
\text { industry and amortizations represent twice as much mass as } \\
\text { production costs. So, amortizations and forecasts, if only } \\
\text { forecasts for rehabilitating sites-when we finish production, } \\
\text { we have to rehabilitate the site-are very important, as they } \\
\text { provide certain room for manoeuvre due to the fact that they } \\
\text { are estimated costs. There are very precise rules-we } \\
\text { amortise at the production unit level, meaning according to } \\
\text { the production of a given well-but it effectively gives } \\
\text { greater leverage when disclosing our results... as we are able } \\
\text { to adjust them in relation to our activity." } \\
\text { (Oil and Gas Industry, Branch Management Controller) }\end{array}$ \\
\hline
\end{tabular}

$\underline{\text { Table } 3 \text { - Practices of Profit Manipulation Operated by Management Controllers }}$ 


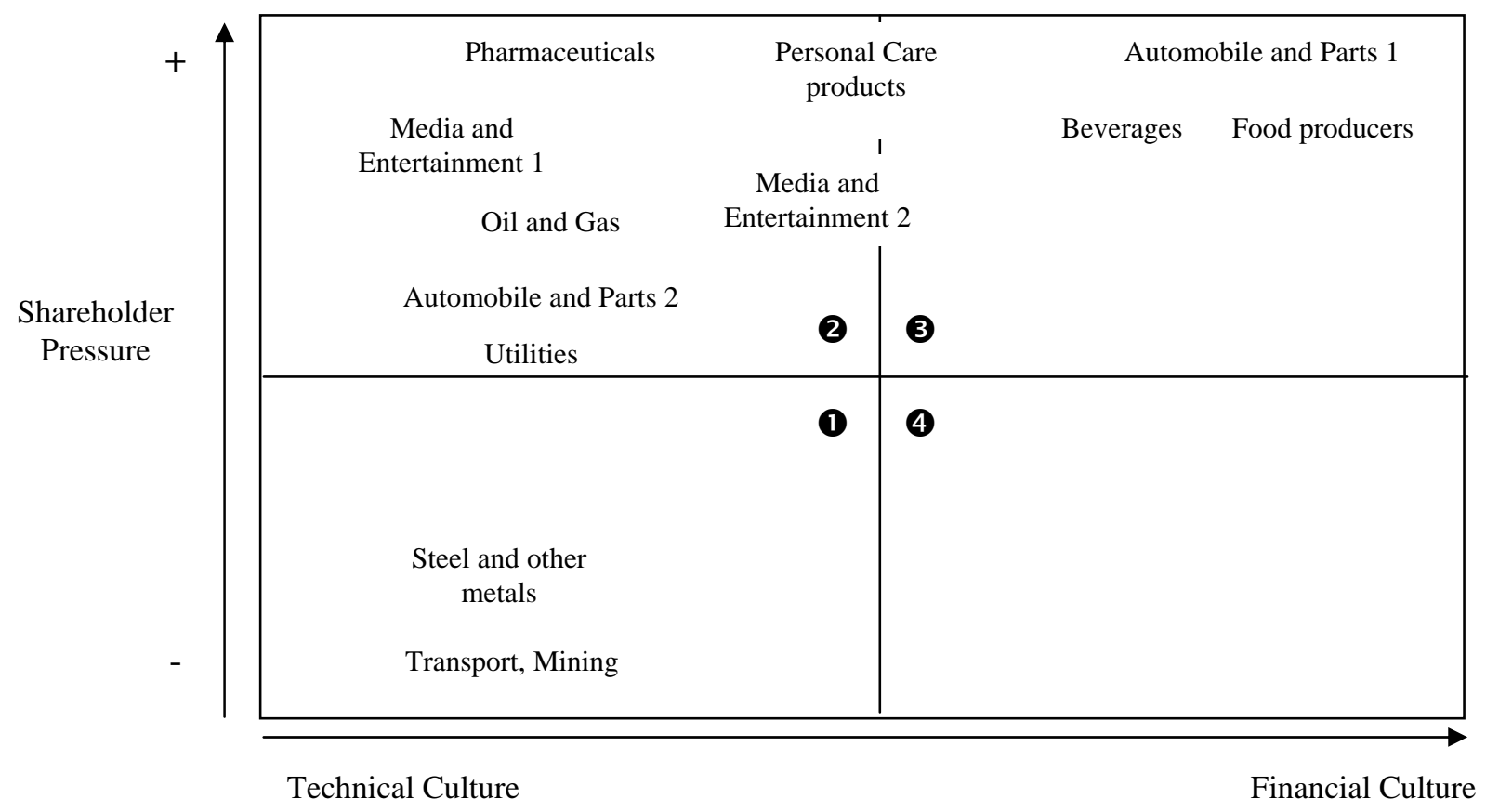

Figure 1: The Positioning of the Different Companies Studied ${ }^{15}$

${ }^{15}$ The companies were placed in this matrix following interviewees' comments and information taken from annual reports and company data available to the general public. 


\begin{tabular}{|c|c|c|c|c|}
\hline & $\begin{array}{l}\text { Configuration } 1 \\
\text { Weak shareholder } \\
\text { pressure, technical } \\
\text { culture dominant }\end{array}$ & \multicolumn{2}{|c|}{$\begin{array}{c}\text { Configuration } 2 \\
\text { Strong shareholder pressure, } \\
\text { Technical culture dominant }\end{array}$} & $\begin{array}{l}\text { Configuration } 3 \\
\text { Strong shareholder } \\
\text { pressure, } \\
\text { Financial culture } \\
\text { dominant }\end{array}$ \\
\hline $\begin{array}{c}\text { Orientation of } \\
\text { Company Culture }\end{array}$ & Technical & \multicolumn{2}{|c|}{ Technical } & Financial \\
\hline $\begin{array}{l}\text { Legitimacy of } \\
\text { Management } \\
\text { Controller }\end{array}$ & Non-existent & \multicolumn{2}{|c|}{ Growing } & Established \\
\hline Profit Manipulation & No & \multicolumn{2}{|c|}{ Yes } & Yes \\
\hline Level of Intervention & N/A & $\begin{array}{l}\text { Heavily capital- } \\
\text { intensive } \\
\text { industries: profit } \\
\text { manipulation is } \\
\text { performed } \\
\text { centrally }\end{array}$ & $\begin{array}{c}\text { Industries } \\
\text { dominated by } \\
\text { marketing: profit } \\
\text { manipulation is } \\
\text { performed at all } \\
\text { levels }\end{array}$ & $\begin{array}{l}\text { Profit manipulation } \\
\text { takes place along the } \\
\text { chain of controllers }\end{array}$ \\
\hline $\begin{array}{l}\text { Incentives for } \\
\text { Management } \\
\text { Controllers }\end{array}$ & N/A & \multicolumn{2}{|c|}{$\begin{array}{l}\text { Legitimising his/her role or technical } \\
\text { skills }\end{array}$} & $\begin{array}{c}\text { Counterweight to a } \\
\text { exclusively financial } \\
\text { orientation }\end{array}$ \\
\hline
\end{tabular}

Table 4: The Three Profit Manipulation Strategies 
Spread of Anglo-Saxon model of corporate

New demands in terms of:

- Value creation

- Transparency

- Frequency of disclosure

- Financial measure of performance

The accounting baseline becomes essential.
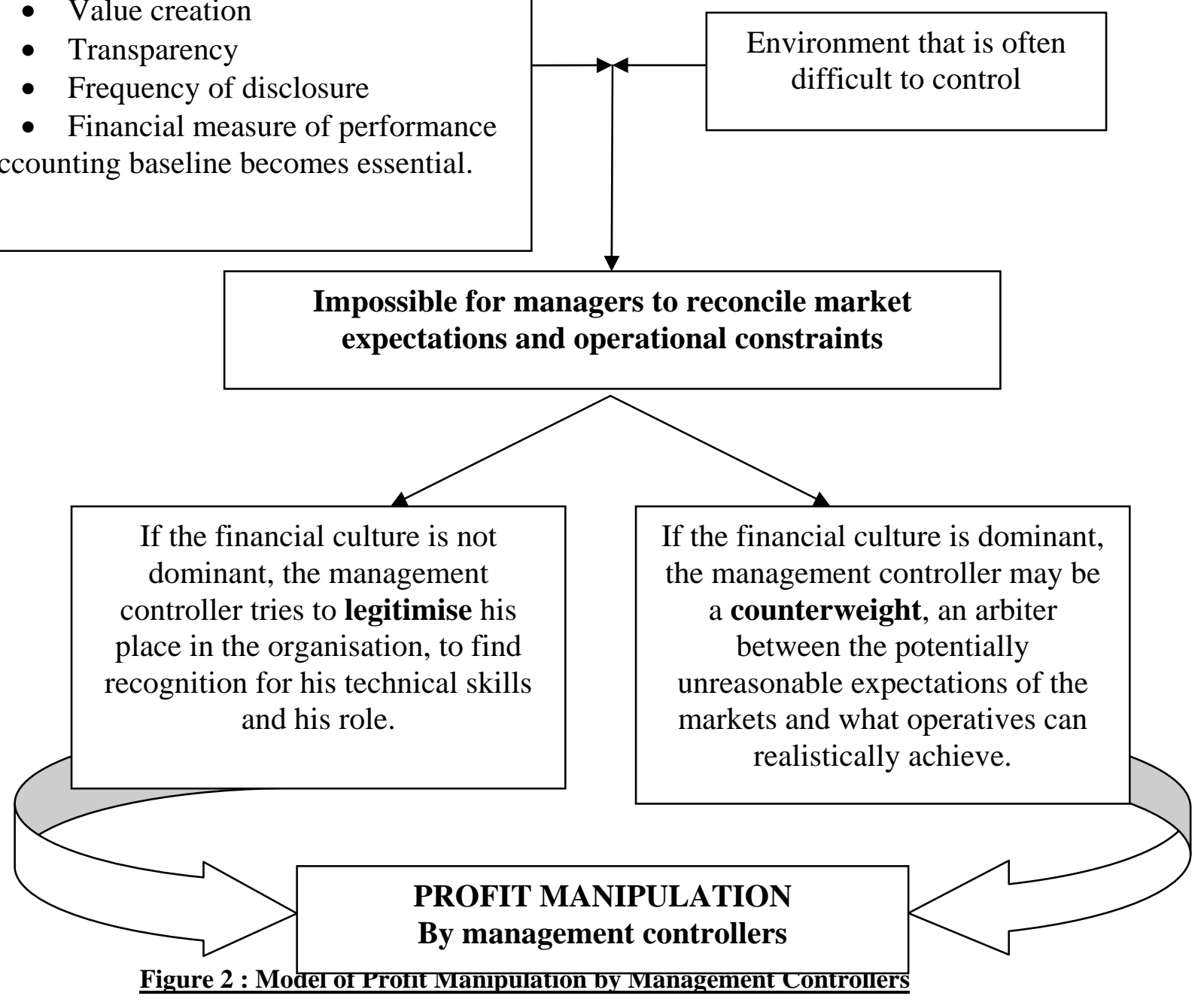